\title{
Súlyos merevedési zavarral küzdő Peyronie-beteg mútéti kezelése Egydio szerinti geometria alkalmazásával, hereburok folttal és egyidejü semirigid péniszimplantátum behelyezésével
}

\author{
Király István Előd dr., Bajory Zoltán dr.
}

Szegedi Tudományegyetem, Szent-Györgyi Albert Klinikai Központ, Általános Orvostudományi Kar, Urológiai Klinika, Szeged (igazgató: Bajory Zoltán dr.)

Levelezési cím:

Dr. Király István Előd

SZTE KK, Urológiai Klinika

6725, Szeged, Kálvária sgt. 57

Email: androkiraly@gmail.com

\section{ÖSSZEFOGLALÁS}

Bevezetés: A Peyronie-betegség kezelésében a konzervatív terápia csak limitált eredményekre képes, így annak kezelése alapvetően sebészi. A domborulati rövidítések az esetek nagy részében kiváló eredménnyel alkalmazhatóak. Ha azonban a görbület 60 fok feletti, vagy a páciens nem fogadja el a hímtag rövidülésével járó technikákat, vagy/és súlyos preoperatív ED-je van a betegnek, más mütéttípusokra van szükség. llyenek a plakk be-, illetve részleges kimetszése graft használatával, péniszimplantátum behelyezése szükség szerint modelláló manőverekkel, illetve a plakk be-, illetve részleges kimetszése egyidejü péniszimplantátum behelyezésével. Értekezésünkben igyekszünk segítséget nyúitani a megfelelő műtéttípus kiválasztásához és esetismertetés formájában bemutatjuk a plakk-bemetszést Egydio szerint, a tunica albugiena defect fedését a here tunica vaginalis parietalis falával és egyidejű szemirigid péniszimplantátum behelyezésével.

Esetismertetés: $\mathrm{A} 62$ éves páciensnek nagyfokú dorsalis görbülete mellett súlyos fokú (IIEF: 6) merevedési zavara volt. A circumcisiós metszést, majd a hímvessző deglovingját követően a neurovaszkuláris köteget elválasztottuk a corpusoktól, majd Egydio szerint kimértük a dupla Y-metszés helyét. Bemetszést követően a szokott módon elökészítettük a corpusokat az implantátum behelyezésére. A nagyméretű tunica albuginea hiány ellenére a szemirigid implantátumot a sulcus coronaris alatt $1 \mathrm{~cm}$-rel ejtett segédmetszéseken keresztül lehetett csak behelyezni. A tunica albuginea hiányt a here tunica vaginalis parietalis lemezével fedtük, amelyet kis scrotalis metszésből nyertünk. A Buck fascia és a circumcisiós metszés zárását követően kompressziós kötést alkalmaztunk. A páciens a negyedik posztoperatív napon távozott osztályunkról. Hathetes kontrollon a hímtag egyenes, telt és hosszú, sebgyógyulási zavar nem látható. Két hónappal a mútétet követően engedélyeztük a szexuális aktivitás megkezdését. A páciens az eredménnyel mind kozmetikailag, mind funkcionálisan maximálisan elégedett.

\section{Plaque incision, grafting and penile prosthesis implantation in Peyronie's disease}

\section{SUMMARY}

Introduction: Peyronie's disease (PD) is an acquired, benign connective tissue disorder that involves the tunica albuginea of the penis and can cause penile deformity and shortening.

Objective: To show when we use other operation techniques than plication in PD and to show a case report using plaque incision by Egydio technique, grafting and implantation of penile prosthesis at the same time.

Patient and method: The 62-year-old patient had a serious, dorsal curvature. His IIEF- 5 score was 6 . After the degloving of the penis, we separated the neurovascular bundle from the cavernous bodies and measured the correct place of the double $Y$ shape incision using Egydio technique. After the incision we inserted an AMS Spectra penile implant in the usual way. We used tunica vaginalis parietalis wall of the testis to cover the defect of the tunica albuginea. We closed the Buck fascia and the skin.

Results: No intra- and postoperative complication. The patient started sexual intercourses two month after the operation. The penis is straight, long and wide. The cosmetic and functional results are excellent.

Discussion: Surgery represents the gold standard of treatment of the PD. The indications for surgery are chronic phase of the disease, the sexual intercourse difficult or impossible, failure of conservative management and erectile dysfunction. The main preoperative factors contributing to the decision of the surgical approach are the severity of the curvature, the quality of the erection and the penile length. The main indications of the implantation of penile prosthesis and incision of the plaque plus grafting are severe penile curvatures (above 60 degrees), large dorsal plaques, ventral cur- 
Következtetés: A nagyfokú görbületek, homokóra alak, a hímtag bicsaklása és/vagy súlyos preoperatív ED és amennyiben a páciens nem fogadja el a pénisz rövidülésével járó technikákat akkor a domborulati rövidítések helyett a plakk bevagy részleges kimetszése és graftolás vagy péniszimplantátum-behelyezés szükség esetén modellálással vagy a plakk bevagy részleges kimetszése egyidejü implantátumbehelyezéssel a választandó mútéttípus.

Az általunk bemutatott Egydio szerinti plakkbemetszés és egyidejü implantátum behelyezés kiváló kozmetikai és funkcionális eredményeket mutat, hasonlóan az azóta elvégzett második esethez.

\section{KULCSSZAVAK}

PEYRONIE-BETEGSÉG, MEREVEdÉSI ZAVAR, EGYDIO SZERINTI PÉNISZPLASZTIKA, PÉNISZIMPLANTÁTUM, PÉNISZHOSSZABBITÁS

\section{Bevezetés}

A Peyronie-betegség (PD) a populáció kb. 7\%-ában fordul elő. A betegség a tunica albuginea hegesedésével jár, ami következményes rövidülést, görbületet, fájdalmat és merevedési zavart okozhat. Feladatunk a beteg számára elfogadható funkciójú pénisz megalkotása. Az egyre jobb eredmények ellenére, a konzervatív terápia csak limitált eredményekre képes. Komolyabb görbületeknél csaknem mindig mútétre van szükség (1). Az operációra akkor kerühhet sor, ha az elváltozás stabil, fájdalom legalább 6 hónapja nem jelentkezett. Amennyiben a görbület 60 fok alatt van, nincs komplex deformitás, nincs homokóra alakzat és a hímtag nem bicsaklik, továbbá a hímvessző hosszcsökkenése a teljes erektilis hossz $20 \%$-át nem haladja meg, a tunica albuginea valamelyik a domborulatot rövidítő technikája javasolt (2). A mútétet követő erektilis diszfunkció (ED) csak 0-13\%-ig jelentkezik, miközben az egyenesség 89\%-100\%-ban elérhető. Ettől eltérő, súlyos, komplikált esetekben plakk be- vagy kimetszés és graftbehelyezés szükséges (3). Ha a tervezett mútét elótt súlyos merevedési zavar áll fenn és az PDE5-I terápiára nem reagál, akkor péniszimplantátum behelyezés is szóba jön. Ha a görbület nagyfokú, a betegnek súlyos erektilis diszfunkciója van és ezt még ronthatja a kisebb péniszhossz, vagy a páciens nem fogadja el a hímvessző rövidülésével járó technikákat, akkor a görbület rövidebb oldalán kialakított metszéssel egyidejü graftolás és implantátumbehelyezés a választandó technika (4). Tanulmányunk célja a Peyronie-betegség komplex rekonstruktív sebészeti megoldásának ismertetése egy eddig Magyarországon nem végzett mútéttípus bemutatásával.

\section{Beteganyag és módszer}

A 62 éves páciensnek a mútétet megelőzően súlyos merevedési zavara volt (IIEF-5: 6 pont), a mons pubisra felcsapott vature, and the presence of residual curvature following penile prosthesis implantation and modeling plus tunical incision.

Conclusion: Choosing the right procedure according to the type of deformity, size of the penis, and preoperative erectile function is necessary in order to obtain the best cosmetic and functional results in PD patients.

\section{KEYWORDS}

PEYRONIE'S DISEASE, GRAFT, PLAQUE, PENILE PROSTHESIS, ERECTILE DYSFUNCTION

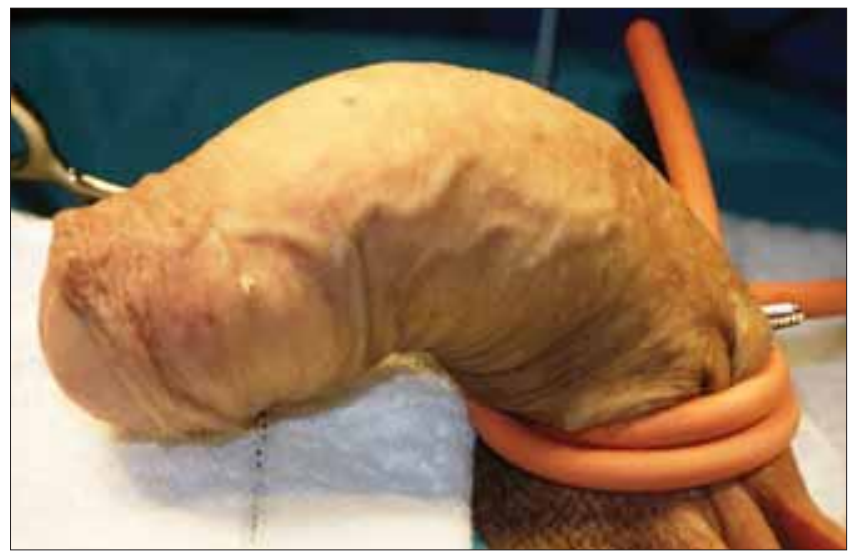

1. ÁBRA: MESTERSÉGESEN KIVÁLTOTT MEREVEDÉSKOR JÓL LÁTSZIK A NAGYFOKÚ DORSALIS GÖRBÜLET

nagyfokú dorsalis görbülettel (1. ábra), ami jelentős hímveszsző-rövidülést okozott. Anamnéziséből kiemelendő kezelt hipertóniája. A nagyfokú görbület és a rövidült hímtag miatt a további rövidülést okozó plikációs technikát a páciens elutasította. Az egy ülésben elvégzendő graft és péniszimplantátum behelyezés mellett döntöttünk. Anyagi okokból a graft mellett biztonságosabban használható felfúijható implantátum helyett szemirigid implantátum beültetését tǔztük ki célul.

\section{Mútét}

Gentamicin és cefuroxim kombinált antibiotikum-profilaxis és 20 perces clorhexidines lemosás után hólyagkatéterezést és a pénisz deglovingját követően, a dorsalis neurovaszkuláris köteget elválasztottuk a tunica albugineától (4. ábra). Múvi merevedés váltottunk ki a corpus cavernosumok fiziológiás sóoldattal való feltöltésével. Egydio technikáját (5) (23. ábra) alkalmazva kimértük (5. ábra) és bemetszettük 


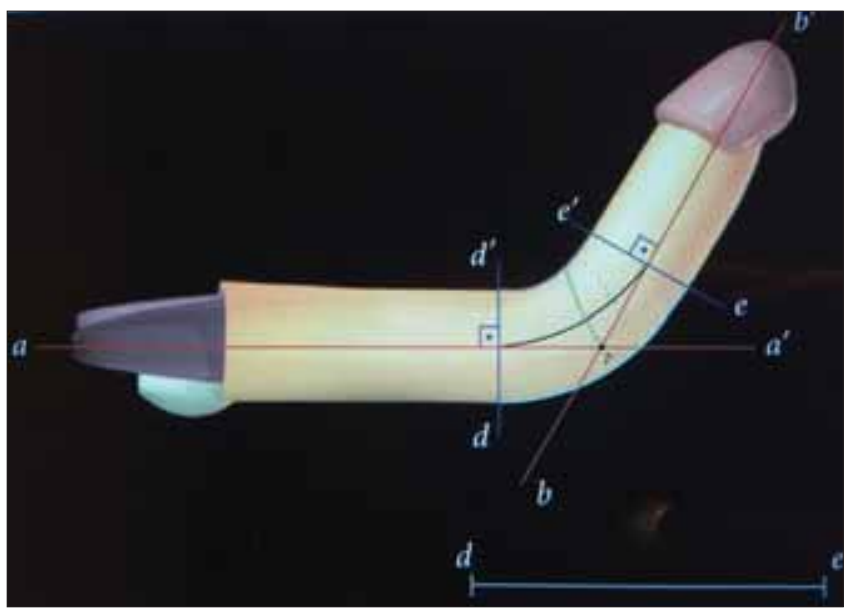

2. Ábra: Egydio geometria: aZ A-A' ÉS A B-B'-K A PÉNISZ TENGELYEI, AMELYEK METSZÉSPONTJAI MEGADJÁK A MAXIMÁLIS GÖRBÜLET HELYÉT. A P-TŐL INDULÓ ZÖLD VONAL ADJA MEG A METSZÉSVONALAT

(ÁTVÉVE: P.H. EGYDIO: A SINGLE RELAXING INCISION TO CORRECT DIFFERENT TYPES OF PENILE CURVATURE: SURGICAL TECHNIQUE BASED ON GEOMETRICAL PRINCIPLES BJU INT 2004; 4: 1147-1157//)

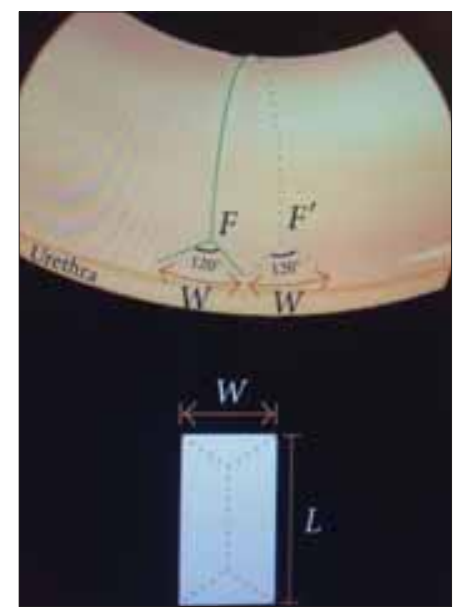

3. ÁBRA: A DUPLA Y-METSZÉSVONAL SZÉLESSÉGÉT, HOGY AZ Y SZÁRAI MILYEN SZÉLESRE NYÍLNAK, A RÖVID ÉS HOSSZÚ OLDAL KÖZÖTTI KÜLÖNBSÉG ADJA, MÍG A 120 FOKOS SZÖG KEZDETÉNEK, A BIFURKÁCIÓNAK A SZÉLESSÉG NEGYEDÉVEL MEGEGYEZŐ TÁVOLSÁGRA KELL KEZDŐDNIE

(ÁTVÉVE: LD. 2. ÁBRA) mútéti területet, majd a circumcisiós metszést egyesítettük (12. ábra). Kompressziós kötést alkalmaztunk a péniszen két napig.

\section{Eredmény}

Intraoperatív komplikáció nem volt. A posztoperatív időszak eseménytelenül zajlott. A beteget a 4. posztoperatív napon bocsájtottuk otthonába.

A graft és a szemirigid AMS Spectra-protézis egyidejú alkalmazása miatt, a páciens csak 2 hónappal a beavatkozás után kezdhette meg a szexuális életet (13. ábra).

A mútétet követően 3 hónappal a preoperatív hímvessző hosszhoz képest $4 \mathrm{~cm}$-es hossznövekedést regisztráltunk, a pénisz egyenes, esztétikailag és funkcionálisan is a páciens teljes megelégedésére szolgál.

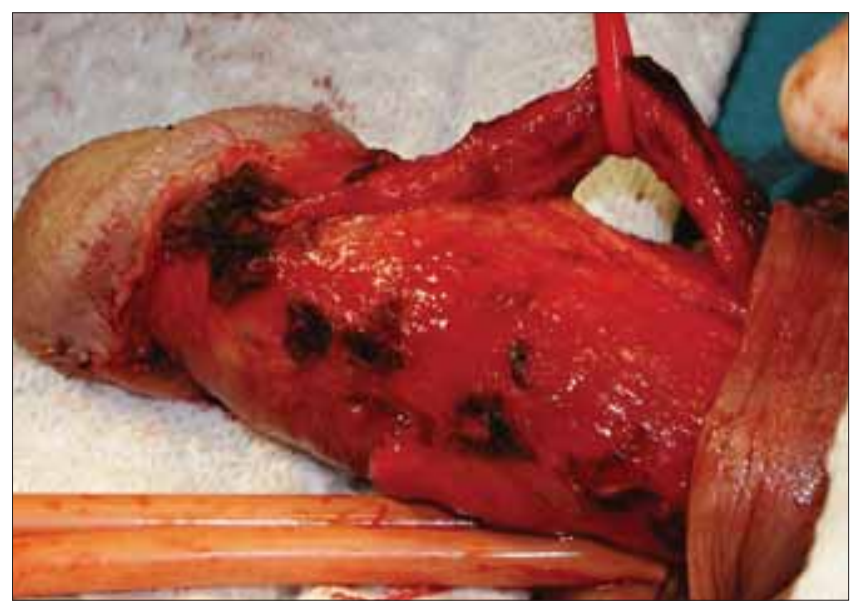

4. ÁBRA: A NEUROVASZKULÁRIS KÖTEGET ELVÁLASZTJUK A TUNICA ALBUGINEÁKTÓL

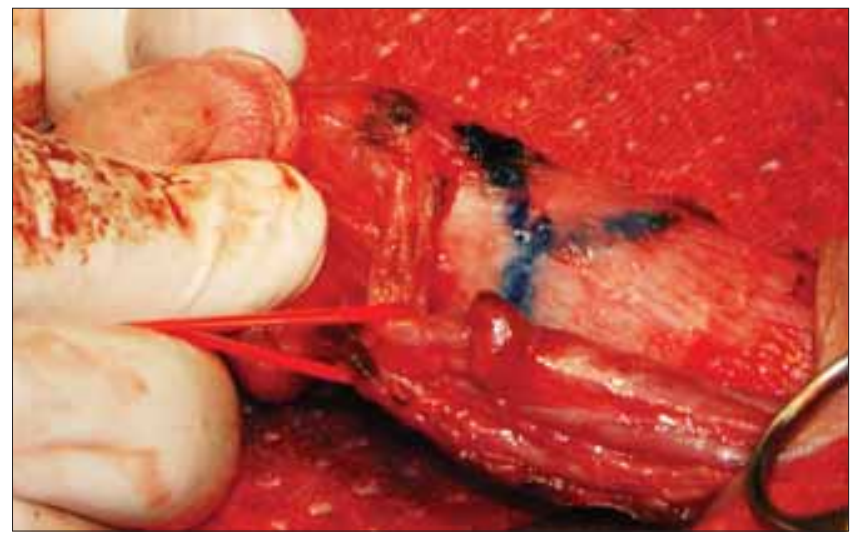

5. ÁBRA: EgYdIO SZERINTI GEOMETRIA ALAPJÁN KIMÉRJÜK ÉS BEJELÖLJÜK A TUNICA ALBUGINEÁK DUPLA Y-BEMETSZÉSÉNEK HELYÉT

\section{Megbeszélés}

Jelenleg a sebészeti megoldás az egyetlen hatékony kezelés súlyos PD-s betegeknek. Ha a betegség stabil, a görbület fokának, típusának, a hímtag hosszának, a preoperatív merevedésnek és a páciens elvárásainak megfelelő mútét választandó. Az esetek nagy részében a domborulati rövidítés kiváló 


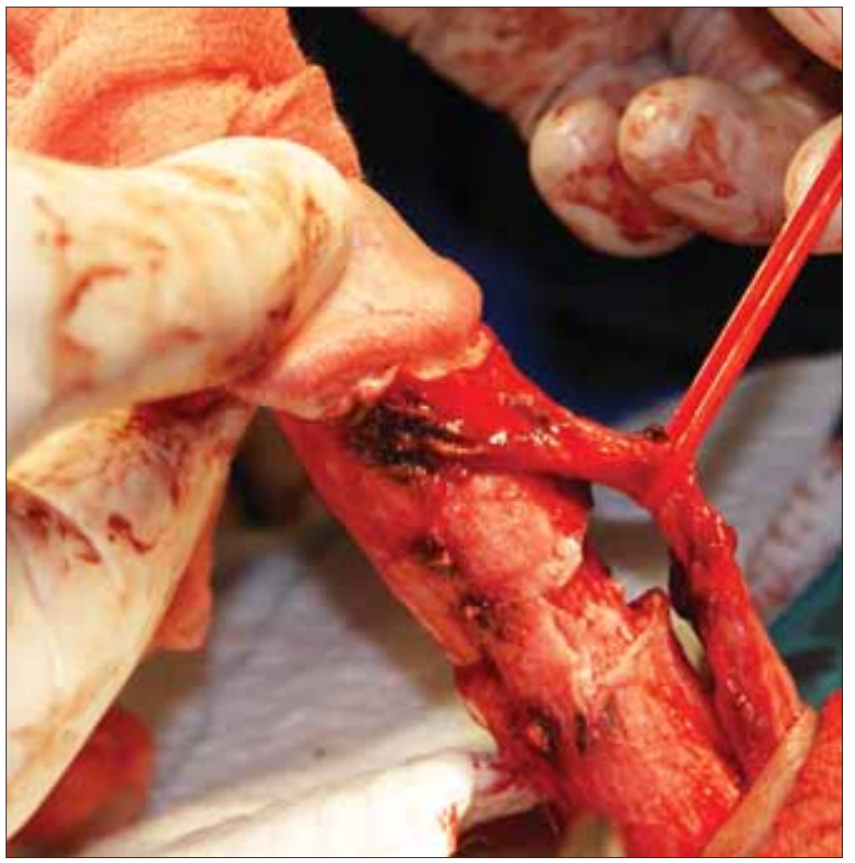

6. ÁBRA: BeMETSZÉST KÖVETŐEN A HÍMVESSZŐ KIEGYENESEDIK ÉS HOSSZA MEGNŐ

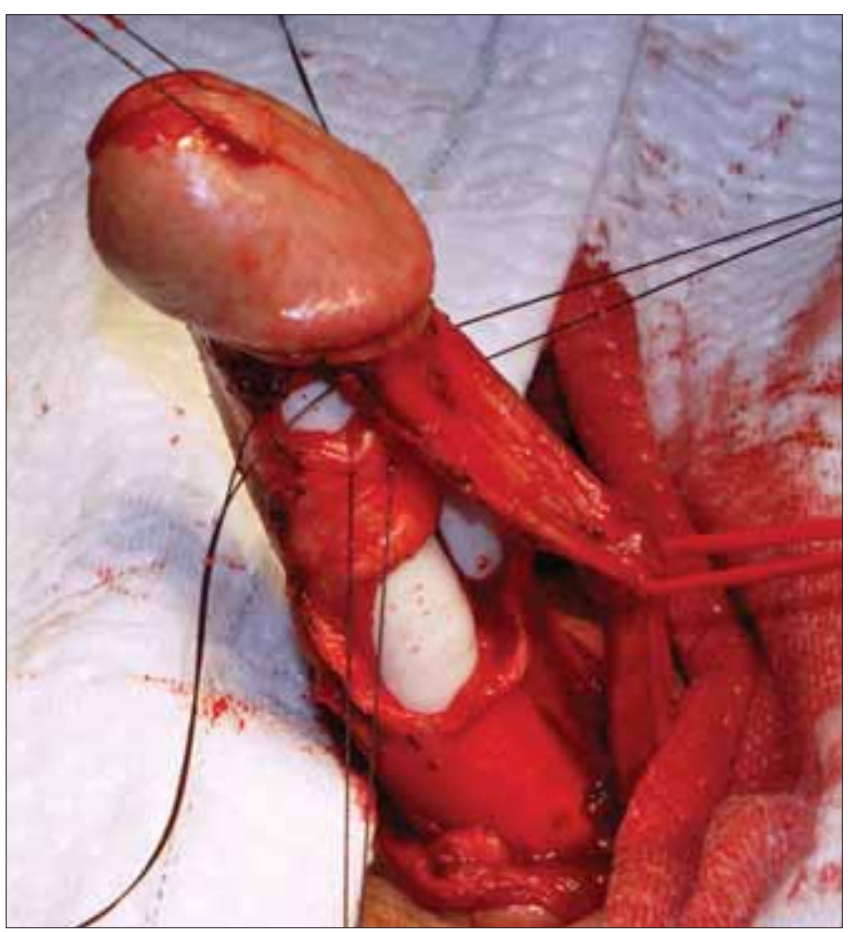

8. ÁBRA: SUbCORONALISAN TOVÁbBI METSZÉSEKET EJTETTÜNK A TUNICA ALBUGINEAN, EZEKEN KERESZTÜL FIXALJUK A 12 MM SZÉLES, 19 CM HOSSZÚ AMS SPECTRA SZEMIRIGID PÉNISZIMPLANTÁTUMOT

eredményt ad, de nagy görbületek esetén is rendelkezésre állnak mútéti technikák, mint a plakkbemetszés, vagy részleges kimetszés graftolással, illetve az implantátum behelyezés modelláló manőverekkel.
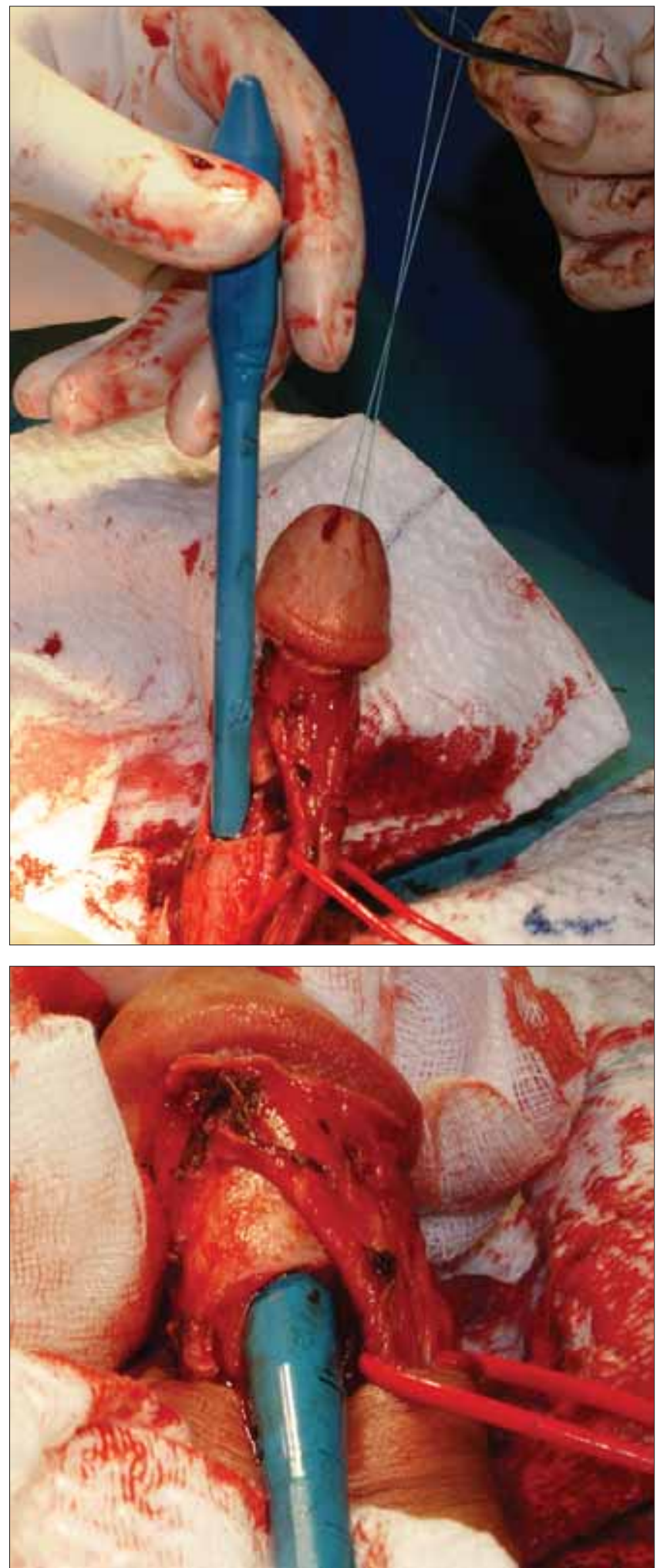

7. ÁBra: A bARLANgos testeket FELTÁgÍTJuK PROXIMÁLIS, MAJD DISTALIS IRÁNYBAN IS

A plakk be- vagy részleges kimetszés graft használatával módszer esetén a hangsúly a részleges kimetszésen van, hiszen teljes kimetszés nem növeli a sikerrátát, ellenben jóval nagyobb graftra lesz szükség, ami a vénás zárómechanizmus ká- 


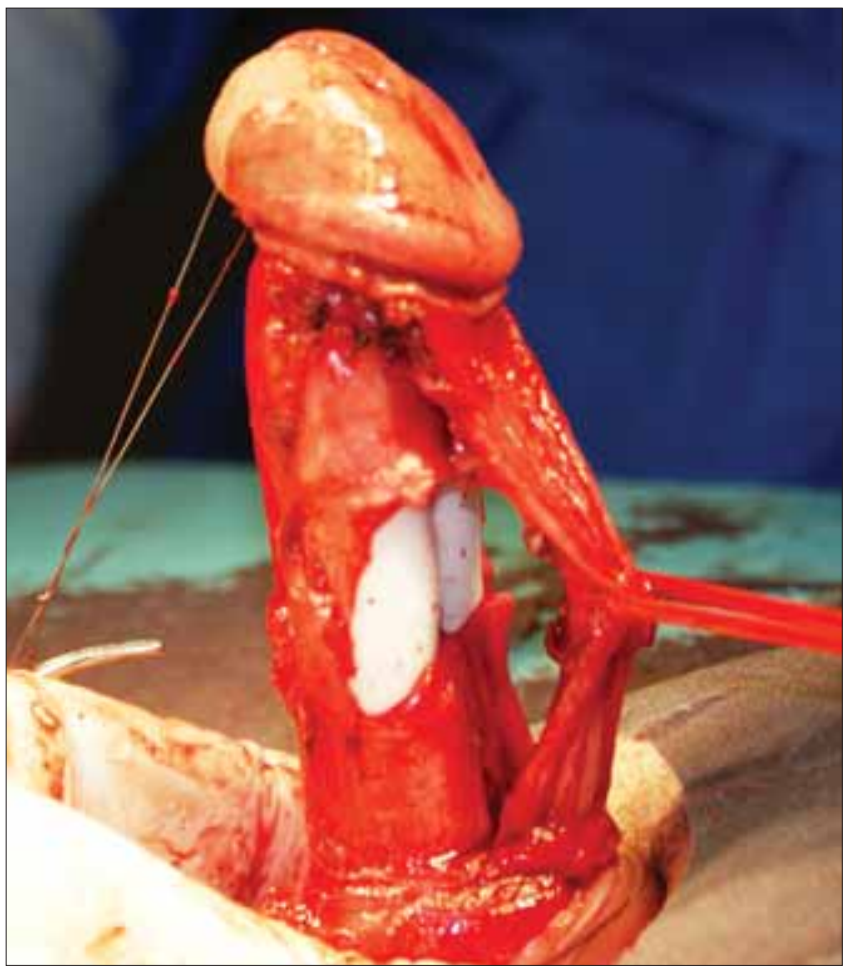

9. ÁBRA: AZ IMPLANTÁTUM BEHELYEZÉSE UTÁN ZÁRTUK A SUBCORONALISAN EJTETT TUNICA ALBUGINEA SEBET

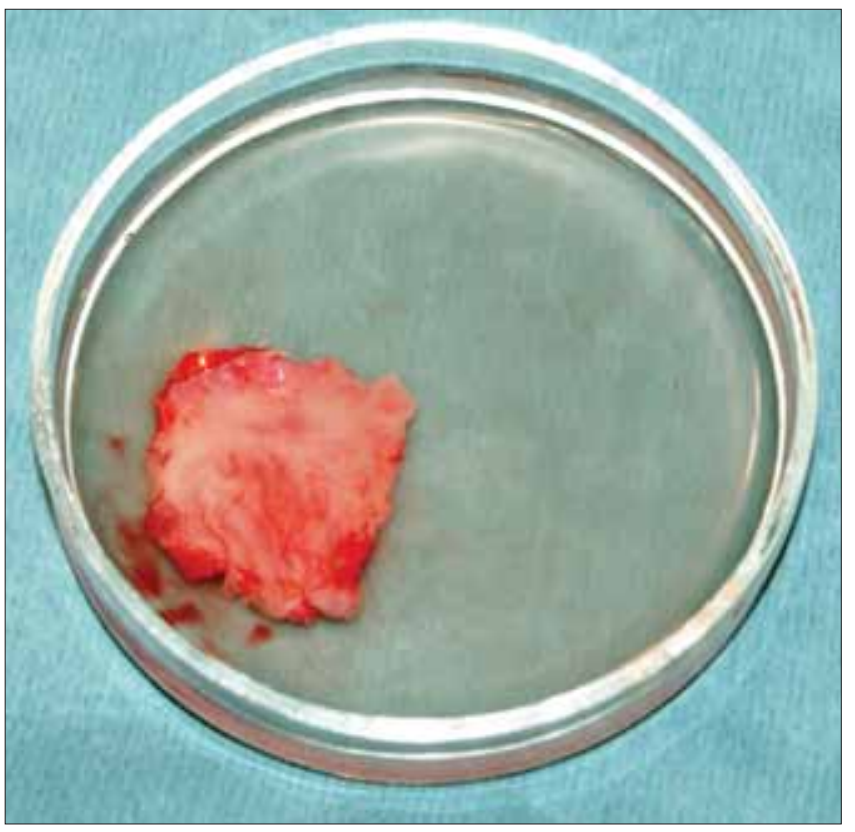

10. ÁBra: A JOBb heRe tUNICA VAGINALIS PARIETALIS FALÁBÓL A TUNICA ALBUGINEA HIATUSNAK MEGFELELŐ MÉRETỦ SZABAD LEBENYT KÉSZÍTÜNK

rosítása révén, magas posztoperatív ED-t okoz. A preoperatív merevedési státusz, az operációs technika (fontos a tunica albuginea bemetszésekor a tunica és a lacunák közötti vékony hálószerú réteg lehetőség szerinti megkímélése) és a graft típusa fontos szerepet játszik a posztoperatív ED kialakulásában. Sok szerző ezért ezt a mútéttípust egyidejú implantáció nélkül, 60 év felett (akinek nagy graftra lesz szüksége vagy ventrális görbülete van) nem is javasolja (6). Az ideális autológ graft könnyen elérhető, kontraktúra nélkül gyógyul a kivétel helye, rezisztens az infekciókkal szemben és megőrzi az erektilis képességet. Leggyakrabban használt autológ graftok a v. saphena, a dermis, a szájnyálkahártya, a rectus fascia, a fascia lata, a here tunica vaginalis parietalis burka. A matrix graftok a borjú vagy kadáver pericardium, malac vékonybél liofilizált submucosa és kadáver fascia lata. Szintetikus graftok a Goretex és a Dacron. Mindegyik graftnak megvan az elónye és hátránya is felhasználhatóság, antigenitás és ár-érték tekintetében. A szintetikus graftok legnagyobb hátránya az általuk kiváltott gyulladásos válasz, ami elfertőződést eredményezhet. Az autológ graftok hátránya a donor oldal gyógyulási problémái, a megnövekedett mútéti idő. Ha lehetőség van rá, a matrix graftok, vagy xenograftok a legjobb megoldások. Fontos megemlíteni, hogy ezen mútétek során csak annyi plakkot metszünk ki amennyi a legkevesebb a tökéletes korrekcióhoz. Sok szerző a dupla Y-incisio és graftbehelyezés mellett ellenoldali plikációs öltéseket helyez be a reziduális kis görbület korrekciója céljából, a plakk-kimetszés és így a posztoperatív ED elkerülése érdekében. A graftmútéteket követően létfontosságú a rövidülés elkerülése céljából a korai PDE5-I terápia vagy vákuumpumpa használata. A mútét hosszú távú eredményei különböző szerzők alapján egyenesség tekintetében 74-100\%, míg posztoperatív ED tekintetében 5-53\% (7). Taylor és Levine hosszú távon $8 \% 20$ fok feletti recidívát és 24\% posztoperatív ED-t találtak, ami kívánatos eredmény lenne. Az mindenképpen leszögezhető, hogy a graft használata a plikációs technikához képest jelentósen növeli a posztoperatív ED kialakulását (8). A páciensnek legmegfelelöbb mútéti típus kiválasztásához keresték azokat a prediktív faktorokat, amik segíthetnek megjósolni a posztoperatív ED kialakulását. Meglepetésre azonban néhány, első ránézésre egyértelmű tényezővel nem találtak összefüggést, mint a betegség fennállásának ideje, kardiovaszkuláris rizikófaktorok jelenléte, a graft mérete, a preoperatív elkeskenyedés vagy bicsaklás (9). Azonban a 60 év feletti kor, a ventrális görbület és a mútétet megelőző csökkent rigiditás jó prediktív faktorai a posztoperatív ED kilakulásának (10).

A másik fontos technika, a péniszimplantátum behelyezése egyidejú egyenesítő manőverrel, azon pácienseknek javasolt, akiknek súlyos merevedési zavaruk van és/vagy nem reagálnak PDE5-I terápiára. Mind a hajilitható, mind a felfújható implantátum jó megoldást jelentenek. A tágítás az esetek nagy részében nem jelent problémát, de körkörös plakk esetén kiterjedt hegesedés, fibrózis lehetséges. llyenkor Rosello cavernotom, Otis urethrotom használata, vagy az implantátum fajtájától függően további distalis vagy proximális corporotomiára szükség lehet. Gyakran ezt követóen az implantátum behelyezése magában megoldja a görbületet, azonban az esetek 19-42\%ában további manőverekre van szükség. 10-20 fokos reziduális görbület nem igényel további beavatkozást. 30 fok feletti 

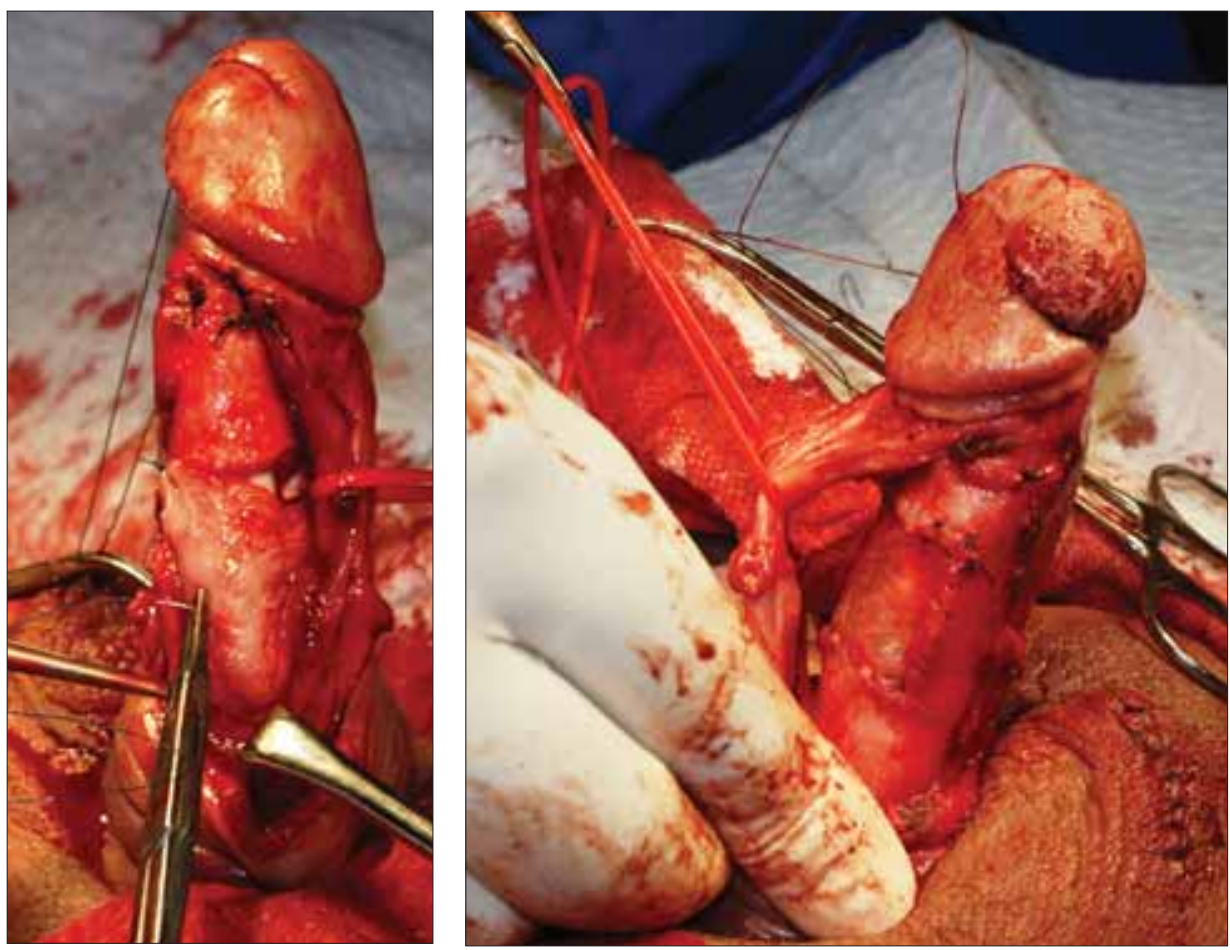

11. ÁBRA: A tUNICA VAGINALIS GRAFTOT TOVAFUtÓ 4/0-S VICRYL-ÖLTÉSEKKEL RÖG= ZÍTJÜK 12. KÉP

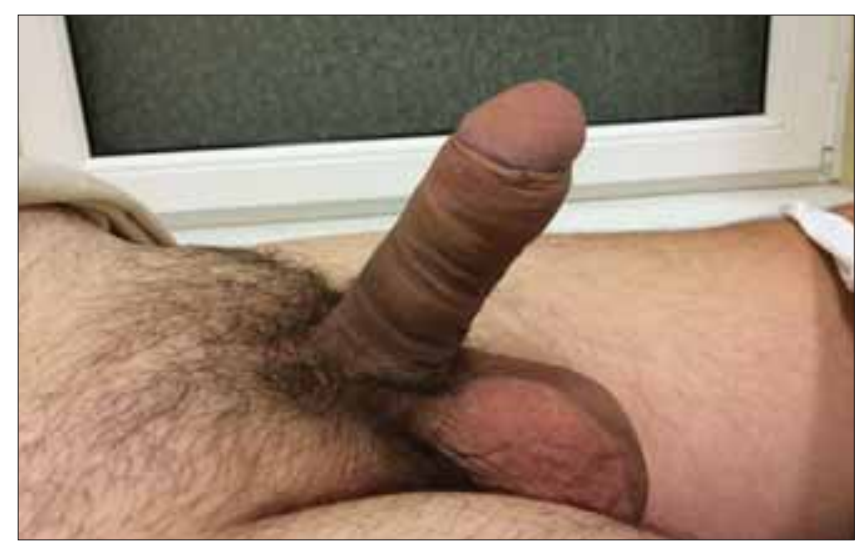

\section{3. ÁBRA: 6 HETES KONTROLL}

reziduális dorsalis vagy dorsolateralis görbületnél a felfújható implantátumokat maximálisan feltöltjük, majd lefogjuk a cilinderekből kilépő csöveket, elkerülendő a manőver hatására kialakuló nagy nyomás szelepkárosító hatása, majd a görbülettel ellentétesen hajilíjuk a hímtagot és 90 másodpercig így tartjuk, majd leengedjük a cilindereket. Végül $80 \%$-ra visszatöltjük őket. Amennyiben nem jártunk sikerrel a beavatkozás egyszer nem szükséges (11). jobb megoldás.

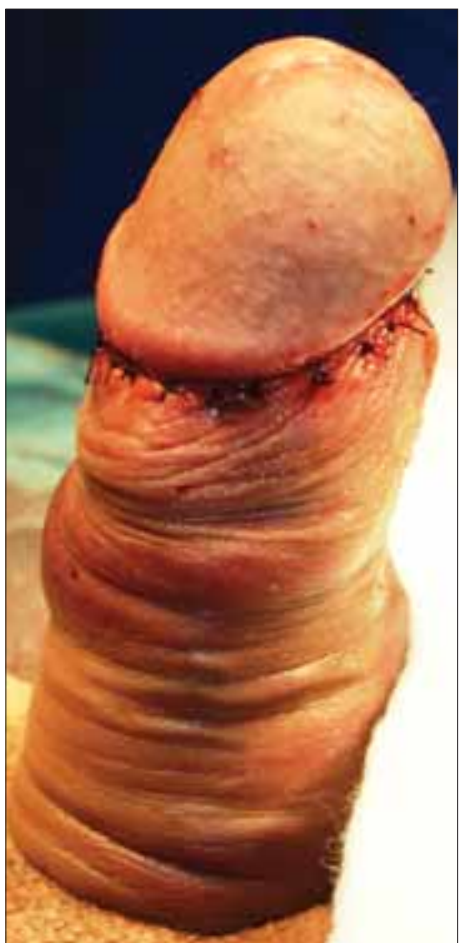

12 ÁBRA: KÖZVETLEN A MÜTÉT UTÁNI ÁLLAPOT

megismételhető. A beavatkozás lényege a plakk szétrepesztése. Hajlítható implantátumok esetén is megkísérelhető ez a technika, azonban itt az eredményesség még gyakorlott kézben is csak 53,8\%, szemben a három részes felfújható implantátum esetén elért 89,6\%-Os sikerrel. Érdemes a gyártónál érdeklődni, mert nem minden típusú implantátum alkalmas erre a durva manőverre. Ventrális görbületnél szigorúan tilos a használata, a típusosan a fossa naviculare magasságában kialakuló húgycsősérülés veszélye miatt. Amennyiben ennek ellenére reziduális görbület áll fenn, relaxációs haránt metszéseket ejthetünk a rövid oldalon. Amennyiben a defektus nem nagyobb 2 cm-nél az aneurizma veszélye kicsi, így graft behelyezése

Az általunk leírt esetben is alkalmazott plakk-incízió + graft + implantátum módszer választandó 60 fok feletti görbület, nagy dorsalis plakk, ventrális görbület esetén, vagy ha implantátum-behelyezést követően sikertelen volt a modellálás és a fesztelenítő bemetszések is. Összegezve azokban a PD-s esetekben, ahol a görbület nagyfokú, vagy a pénisz eleve rövid és már a mútét előtt súlyos ED detektálható, ott a plakk-incízió, graftolás és a péniszimplantátum egyidejú behelyezése a leg- 


\section{Irodalom}

1. Kelemen Zs, Szúcs M, Majoros A, Romics I. Az induratio penis plastica sebészi kezelése. Magy Andrológia 1999; 4: 49-54.

2. Nyirády P, Rusz A, Szász A, Sulya B, Kelemen Z, Romics I. Erectile function and sexual satisfaction after contralateral corporoplasty for congenitale and aquaired penile curvatures (Peyrone's disease)Long term patients' view JOURNAL OF SEXUAL MEDICINE 2005; 2:(Suppl): 111

3. Kelemen Zs, Donáth A, Pánovics J, Pajor L. Az induratio penis plastica sebészi gyógyítása szövetpótlással. Orvosi Hetilap 1982; 123: 2099-2105.

4. Ralph D, Gonzalez-Cadavid N, Mirone V, et al. The management of Peyronie's disease: evidence-based 2010 guidelines. J Sex Med 2010; 7: 2359-74. https://doi.org/10.1111/j.1743-6109.2010.01850.x

5. Egydio PH, Lucon AM, Arap S. A single relaxing incision to correct different types of penile curvature: surgical technique based on geometrical principles BJU Int 2004; 94: 1147-1157. https://doi.org/10.1111/j.1464-410X.2004.05220.X
6. Levine LA, Larsen SM. Surgery for Peyronie's disease. Asian J Androl 2013; 15: 27-34. https://doi.org/10.1038/aja.2012.92

7. Chung E, Clendinning E, Lessard L, Brock G. Five-year follow-up of Peyronie's graft surgery: outcomes and patient satisfaction. J Sex Med 2010; 8: 594-600. https://doi.org/10.1111/j.1743-6109.2010. 02102.x

8. Almannie R, Carrier S. Sexual Dysfunction after surgical treatment of Peyronie's disease J sexol 2012; 21: 48-54.

9. Raanan Tal, Stefan Flores, Judy Choi, Alex Byron, Christian J. Nelson, John P. Mulhall. The Fate of Patients Developing Erectile Dysfunction after Plaque Incision and Grafting for Peyronie's Disease Journal of Urology 2013; 4S: 189.

10. Frederic L. Taylor, Michael R. Abern, Laurence A. Levine Predicting Erectile Dysfunction Following Surgical Correction of Peyronie's Disease without Inflatable Penile Prosthesis Placement: Vascular Assessment and Preoperative Risk Factors J Sex Med 2012; 9: 296301. https://doi.org/10.1111/j.1743-6109.2011.02460.x 